\title{
The Family Thought of Marx and Engels and Its Enlightenment in the New Era
}

\author{
Tingting Wang \\ Southwestern University of Finance and Economics, Chengdu 611130, Sichuan, China \\ Email: 397980375@qq.com
}

\begin{abstract}
In the Marxist theoretical system, "family" is a very important theoretical category, which is not only the "mystery" Marx and Engels has been trying to solve, but also an important reflection of Marxist philosophy. Marx and Engels held the conviction that the development of the family went through the consanguinity family, the Punaluian family, the paring family and the monogamous family. Marital relationship is the basis of forming a family; blood relationship is the bond of forming a family; family is the organizational form of human social life. Those are the essential characteristics of family. In the new era, while promoting the harmonious development of family, we must know the harmonious marriage relationship is the foundation of family harmony, and that the harmonious parent-child relationship is the key to family harmony. Meanwhile, we should pay attention to the harmonious unity of family and society.
\end{abstract}

Keywords: Marx, Engels, family thought, family harmony

With the transformation of the main social contradictions in the new era, the needs of families are more and more diversified and personalized, which have posed severe challenges to the original family structure, family function and family relations. From an overall and strategic perspective, President Xi Jinping has made a series of important discussions on the construction of family traditions, emphasizing the importance of family construction in the new era. In this context, the in-depth study of Marx and Engels' family thought for the new era of family construction provides valuable theoretical reference and enlightenment.

\section{The development form of family}

Marx and Engels conducted an in-depth analysis of the development process of prehistoric human society on the basis of Morgan's family history research, combining a large number of reliable empirical materials. They affirmed Morgan's view that "the concept of the family has gone through several successive stages of development before reaching maturity"[1], holding that the family is concrete and historical, and family depends on the development of productive forces in the final analysis, and concluded the different forms of family development.

\subsection{Consanguine family}

The consanguinity family is the first family form from the primitive promiscuous sexual relations, which belongs to the initial stage of the group marriage system. During this period, people's hunting skills had been improved to a certain extent. In order to obtain more food sources, the division of age came into being. Men and women of similar age form groups, hunt together and live together, which naturally causes the original group to split up and the transition was made from promiscuous sexual state to blood family. That is, as Marx said, "In order to make a living, a primitive group must break up into small groups and to form blood families"[2]. Consanguinity families are characterized by intermarriage between siblings. Marx and Engels further pointed out that the existence of blood family is the premise of all subsequent family evolution, it first made provisions for the original promiscuous sexual relations, and restricted the sexual relations between different generations, which was the first progress in the development of the family.

\subsection{The Punalua family}

The second form of family development was the Punalua family, which was an advanced stage of communal marriage. During this period, people began to forbid the intermarriage between brothers and sisters because they found that the intermarriage was harmful to their offspring in practical life, and the intermarriage system was implemented. In this family structure, a group of sisters of the same age and a group of brothers of the same age got married together, that is, "mutual co-husband and co-wife within a certain range of families" [3], but the man's own brothers and the woman's own sisters were excluded. The husbands no longer call each other brothers, and the wives no longer call each other sisters. Instead, they call each other punaluya (Hawaiian), which means "intimate partner". The bonding of the sexes in the Punaluian family was no 
longer based on blood relations. This limitation of consanguinity was not only a great ethical and moral progress, but also improved the intelligence and physical ability of the offspring, promoted the development and strength of the tribe, and thus established the clan.

\subsection{Pairing family}

The third form of family that followed the Punalua family was the pairing family. It is no longer a form of group marriage, but an unstable family form in which a man and a woman were united. This kind of family form had already begun under the system of group marriage, that is, men have one master wife among many spouses, and women have one master husband among many spouses. However, with the development of the clan and the frequent communication between the clan, the men's visits made women to feel with pressure and shame, and the group marriage gradually transferred to the pairing family. Under the communist family economy, the family was isolated from the society, and the production of the family was only to meet the needs of each member of the family, rather than to be used for exchange. Women had the same power as other family members to coordinate and manage the production and distribution of the family. As Engels mentioned, "Everyone is equal and free, including women" ${ }^{[4]}$. But in the later period of the paired family, with the improvement of productivity, the appearance of metal tools, and the development of agriculture and animal husbandry, men began to dominate the production. At the same time, as men mastered private property and their economic status was greatly improved, they had the desire to let their own children inherit the property, which accelerated the decline of the pair family and the collapse of the matriarchy.

\subsection{Monogamous families}

The pairing family was followed by the monogamous family, which consist of a man and a woman. The biggest difference between the monogamous family and the pairing family is that the marriage relationship cannot be dissolved at will. The monogamous family is the result of the development of productive forces and the establishment of ownership of means of production. The monogamous family is finally established when the level of productivity is high enough to allow the individual family to become an independent productive unit and social cell. The monogamous family was finally established when private ownership was established, requiring children to inherit their father's property. In monogamous families, men are dominant and have the right to dissolve the marriage, while women gradually lose their voice and can only rely on their husbands. Thus so-called monogamy is in fact exclusive mating of the wife, which failed to pose limitations on the "overt or secret polygamy" of the husband ${ }^{[4]}$. This suggests that monogamous families are the product of economic relationships based on private property, rather than "the result of personal sexual love"[3].

\section{The essential characteristics of the family}

Marx and Engels believed that the essential characteristics of the family were hidden in various forms of the family itself, which was accompanied by the whole process of family changes. The essential characteristics of the family mainly include three inseparable aspects.

\subsection{Matrimonial ties are the foundation of a family}

From the actual process of the evolution of family history, it is not difficult to find that the matrimonial ties between men and women is the common basis of the evolution of family history. Marx and Engels believed that the foundation of family is the sexual relationship between husband and wife, which exists in the conclusion of human marriage from the very beginning. The promiscuous sexual relations in the primitive society, the elimination of the sexual relations between different generations in the blood family, the restrictions on the sexual relations between brothers and sisters of the same father and mother in the Punaluya family, and the unstable relationship between husband and wife in the dual family can be removed at any time. The loss of women's family status in monogamous families and the fact that love becomes the basis of marriage in the future communist families all show that sexual relations have existed since the existence of human beings and are the basis for the formation of family relations.

\subsection{Blood ties are the ties that bind families together}

The blood relationship plays a special role in the mutual connection between family members, which connects family members into a stable community. Father, mother and child form a stable family triangle, and parents bear the responsibility of raising and educating their children. From the first skills of picking and hunting, to the techniques of making and using tools of production, to the expression and recording of language and writing, to the present guidance of thought, although with the continuous development of productive forces, the content of parents' education for their children has changed greatly, every generation of parents had been trying to do a good job in their role in upbringing and education, and the family is closely linked under this strong blood relationship. 


\subsection{Family is the organization form of social life of human beings}

Family is not a simple "relationship" form, but a form of social organization in which people live together. Organized by marriage and consanguinity, people cohabit and eat together, forming a living community that supports each other in economy and influences each other in thought and emotion. It is based on marital ties and tied by blood ties, so it also bears the responsibility of procreation, upbringing and education. These responsibilities are fulfilled not only by biological means, but also by social means, which closely link people's own production with the production and consumption of material goods. In the agricultural society, due to the limitation of productive forces, families include various life contents such as labor, creation and consumption, forming a complete social life community. With the development of productive forces, social production is gradually separated from the family, and the family becomes a community of consumption of means of living.

\section{Enlightenment in the new era}

Whether a family is harmonious or not is not only related to the family members themselves, but also affects the stable development of the whole society. The family thought of Marx and Engels enlightens us that the harmonious development of family in the new era should be based on the organic unity of the harmonious marriage relationship, the harmonious intergenerational relationship, the harmonious family and social relationship.

\subsection{A harmonious marriage relationship is the basis of maintaining a harmonious family}

First, marriage is based on love.Marx and Engels first emphasized that "love" was the "only basis" for marriage. Engels pointed out that "mutual love between men and women should be above everything else"[3], which failed to be replaced by anything. With the development of China's socialist market economy, the status of money in people's hearts is increasing, and many young men and women are more inclined to sacrifice love and surrender their marriage for material things. In such historical background, it is especially important to promote love. At the same time we should note that Marx and Engels said that love is the only basis of marriage and it is based on great material production. Although socialism with Chinese characteristics has entered a new era and people's economic conditions have been greatly improved, there is still a certain gap between love and marriage as the only basis. Therefore, while actively advocating a marriage based on love, we should not make a negative moral evaluation of men and women who consider economic conditions when choosing a mate.

Secondly, integration of freedom of marriage and self-restraint. Marx and Engels believed that marriage is free, but the freedom of marriage is limited to certain scope rather than arbitrary marriage and divorce. With the deepening of reform and opening up and economic globalization, the concept of freedom of marriage is gradually misunderstood while deeply rooted in people's hearts. Many people pursue love and sex beyond marriage under the guise of love, which leads to the decline of trust between husband and wife. They ignored the exclusivity of love and marriage and absolutized the freedom of marriage. While enjoying the freedom of marriage, the husband and wife should also take single-minded and faithful as the bottom line to maintain the marriage relationship, and they should actively fulfill moral obligations, undertake family responsibilities, and combine the freedom of marriage with self-restraint.

\subsection{The harmonious parent-child relationship is the key to maintaining the harmonious family relationship}

First, we should care and educate our children in a rational manner. Marx and Engels believed that parents should not only "nurture" their children, but also "love" and "nurture" them in a reasonable way. When Chinese parents overindulge their children, they also take them as a tool to realize their own personal ideals. Once their children deviate from their expectations, they will be denied and criticized. This way of caring and education is easy to aggravate children's rebellious psychology towards their parents, which is not conducive to the formation of a harmonious parent-child relationship. To realize the free and comprehensive development of human beings is Marx and Engels' outlook on family education of the times. Parents should follow the laws of children's natural development and stimulate their development potential. At the same time, parents, as children's first teachers, should set an example and integrate education and emotion to cultivate children's good moral character. President Xi Jinping also mentioned that there are many noble qualities he should learn from his father ${ }^{[5]}$.

Secondly, the elderly should be accompanied with love. The unity and harmony of a family is not only the selfless care and good education of the elders to the younger generation, but also the understanding and gratitude of the children to the elderly. At present, China is in the process of social transformation and demographic transformation with the advancement of urbanization, the continuation of low fertility rate, the change of family concept and the improvement of housing conditions and facilities, the traditional extended family is gradually replaced by the nuclear family formed by a husband and wife and 
their unmarried children. This small family model can quickly adapt to the socialist market economy, which give rise to the separation of the younger generation from the older generation, resulting in the absence of family warmth and emotional care. The elderly should be the center of the family. While actively meeting their material needs, children should pay more attention to the emotional needs of the elderly, accompany and take care of them from time to time, and let them rely on their old age.

\subsection{Harmony and unity between family and the society}

Firstly, families should actively adapt to social changes. As one of the organizational forms of human social life, families are the product of certain productive forces, production relations and social system, which are closely related to the whole social form. Marx and Engels believed that the family must change with the change of society. Since the 21 st century, the external impact brought by the modernization transformation, such as marketization, globalization, acceleration of urbanization, popularization of the Internet and the progress of modern medicine, has prompted great changes to the family once again. For example, sexual behavior and reproductive behavior are gradually separated, the family based reproductive function is weakened, the family size is miniaturized, the families in the new era are experiencing a "modern revolution", the families should conduct active adjustment to adapt to the changes of new society.

Secondly, to view the society from the perspective of family and promote the harmony and unity of the two sides. In the view of Marx and Engels, the family is the natural basis and necessary condition of the existence of the state and society. The family is a micro society, and the changing characteristics of family structure, family function and family relationship also reflect the social problems that China is facing at present. For example, the miniaturization of the family scale and the empty-nesting of the family will further weaken the function of the family care for the aged with the severe problem of our society in pension. To some extent, the increase of the proportion of stepmarried families reflects the increasingly prominent social problem in stepchild education. Through the perspective of the family, we can examine the current social changes and social problems, so as to promote the harmony and unity of the two.

\section{Conclusion}

Family, as a quiet harbor, is the place of our soul. At the same time, family is also the cell of society, which is closely related to the development of society. Marx and Engels comprehensively discussed the various forms of family development, scientifically explained the essential characteristics of the family, and provided action guidelines for promoting the harmonious development of the family. At present, China is in the period of socialist transition. Although some progress have been made in the family development, there are still many difficulties and problems. Although the social situation and family problems in the new era are very different from those of Marx and Engels at that time, it does not mean that their family thoughts are out of date. The essence of their thoughts still shows fresh vitality. On the whole, family construction in the new era can be achieved with the value of times of Marx and Engels' family thought, and the study of Marx and Engels' family thought can better guide us to understand the connotation of Xi Jinping's thought on family and construction thought of family style so as to correctly grasp the development direction of family construction in the new era.

\section{References}

[1] Louis Henry Morgan. Ancient Society[M]. Translated by Yang Dongchun et al. Beijing: The Commercial Press; 1977: 381.

[2] Abstract from Morgan "Ancient Society"[M]. Beijing: People's Publishing House; 1965: 20.

[3] Bureau of Compilation and Translation of Works by Marx, Engels, Lenin and Stalin, CPC Central Committee. Friedrich Engels. Family, private ownership and the origin of the state [M]. Beijing: People's Publishing House; 2018.

[4] Bureau of Compilation and Translation of Works by Marx, Engels, Lenin and Stalin, CPC Central Committee. Selected Works of Marx and Engels (Volume 4)[M]. Beijing: People's Publishing House; 2012.

[5] Editorial Group of Xi Zhongxun's Revolutionary Career. Xi Zhongxun's Revolutionary Career[M]. Beijing: Chinese Culture and History Publishing House/ Beijing: CPC History Publishing House; 2002: 668-669. 